\title{
William Osler and the jubjub of ethics; or how to teach medical ethics in the 21 st century
}

Daniel K Sokol

J R Soc Med 2007; 100:544-546

\section{INTRODUCTION}

William Osler (1849-1919) was arguably the world's most famous physician at the turn of the 20th century. Although his writings are diverse and prolific, there is remarkably little on the subject of medical ethics. ${ }^{1,2}$

This absence is not, I believe, a result of Osler's lack of interest in matters medico-ethical, even at a time when such issues were perhaps not as complex as they are today. The reason is that his focus was on character and virtues, rather than on particular moral problems and individual actions. His moral outlook was predominantly agent-based, not actbased. He was concerned with the 'good' doctor, the 'good' teacher, the 'good' student, and these were frequently defined by their desirable habits, dispositions, and character traits.

\section{OSLER THE VIRTUE ETHICIST}

Today, Osler would be considered a virtue ethicist. Although virtue ethics can be traced back to Plato and Aristotle, it enjoyed a revival roughly 40 years ago, partly as a result of the deadlock between proponents of deontology — a set of moral theories focusing on duties and rulesand consequentialism - a set of moral theories focusing on desirable consequences of actions. ${ }^{3}$

In virtue ethics, the question is not 'What is the right thing to do here?' but 'What would a virtuous person characteristically do in this situation?'. If a sick patient asks for a grim prognosis, the virtue ethicist might ask 'How would a benevolent, honest, compassionate, wise and just doctor respond in this situation?'.

On several occasions, Osler emphasized the importance of what he called the 'education of the heart'.

'The education of the heart - the moral side of man-must keep pace with the education of the head. Our fellow creatures can not be dealt with as man deals in corn and coal.' ${ }^{4}$

'The physician needs a clear head and a kind heart; his work is arduous and complex, requiring the exercise of the very highest

Lecturer in Medical Ethics and Law, St George's, University of London, Cranmer Terrace, London SW17 0RE, UK; Honorary Research Fellow, Imperial College, London faculties of the mind, while constantly appealing to the emotions and finer feelings. ${ }^{5}$

'Be careful, when you get into practice, to cultivate equally well your hearts and your heads.' 6

In this age of ubiquitous technology, strict guidelines and protocols and fleeting consultation time, the heart is perhaps more prone to neglect than ever before. Howard Brody warns of seeing patients as slabs of meat to be shipped from one part of the hospital or health system to another, and others too have argued for the importance of empathy and the emotions to good clinical practice. 7,8

The first person to express virtue ethics systematically was Aristotle, whom we know Osler greatly admired:

'No man has ever swayed such an intellectual empire - in logic, metaphysics, rhetoric, psychology, ethics, poetry, politics and natural history, in all a creator and in all still a master.' 9

It is highly likely, then, that Osler was familiar with Aristotle's views on the virtues. In The Master-Word in Medicine, an oration delivered at the University of Toronto in 1903, Osler also quotes Plato, another founding father of virtue ethics:

'On account of the intimate personal nature of his work, the medical man, perhaps more than any other man, needs that higher education of which Plato speaks_- "that education in virtue from youth upwards, which enables a man eagerly to pursue the ideal perfection".' 10

\section{THE LIMITS OF BOOK- AND CLASSROOM- ACQUIRED MEDICAL KNOWLEDGE}

Osler was an avid reader and bibliophile. He believed that reading was a way of interacting with great minds, thus refining one's own, contributing to the development of virtues and the 'education of the heart'. 'Start at once a bed-side library' Osler enjoined in The Master-Word in Medicine, 'and spend the last half hour of the day with the saints of humanity'. ${ }^{10}$ Although book- and classroom-based methods could produce learned students, Osler believed they were poor substitutes for ward-based instruction. ${ }^{10}$ 
'I desire no other epitaph — no hurry about it, I may say — than the statement that I taught medical students in the wards, as I regard this as by far the most useful and important work I have been called upon to do.' 10

While the value of teaching medicine in the wards is today self-evident, the idea of teaching medical ethics at the bedside is very seldom heard. Although this is not the place to embark on a profound examination of the nature of medicine, ethics is an integral part of medicine. Since medicine - to paraphrase the late haematologist Jean Bernard - is fundamentally about man, and ethics is mainly about how we should interact with others, medicine and ethics are inseparable bedfellows. ${ }^{11}$

In 1978, Mark Siegler, an American physician and clinical ethicist, proposed the idea of bedside medical ethics teaching, and it has since been implemented in some parts of the USA. ${ }^{12,13}$ The advantages of this method are many: students deal with actual cases on-site and can observe situations for themselves; are less likely to see medical ethics as abstract or removed from reality; can better appreciate the relationship between the technical and the ethical; can witness the wealth of ethical issues arising in the clinic; can improve their moral perception; and may be less prone to the erosion of moral principles. ${ }^{12,13}$ One study showed that $62 \%$ of medical students surveyed believed that 'some of their ethical principles had been eroded or lost' during the course of their medical training. ${ }^{14}$

In spite of these advantages, the formal teaching of medical ethics in the wards is, to the best of my knowledge, rare in the UK. ${ }^{15}$

\section{THE DENIAL OF 'FORMAL’ MEDICAL ETHICS TEACHING}

It is only in the last 15 years that medical ethics has featured as a core component in the UK medical curriculum. ${ }^{16}$ There are thus many practising clinicians who have received no formal training in ethics. Professor Raanan Gillon, who trained in the 1960s, wrote:

'Consideration of medical ethics has moved a long way since my own days as a medical student, when I was told that it basically boiled down to doing as my teachers did, and told me to do.' ${ }^{\text {'17 }}$

This is no doubt an effective method if the teachers are good, and a disastrous one if not. In the absence of universally good teachers, medical students and junior doctors could benefit greatly from ethics training when facing the many ethical issues they will encounter in their work, from telling patients the truth to managing the limits of their own competence and addressing the inappropriate behaviour of colleagues.
A knowledge of medical ethics is not acquired by intuition alone: it can be taught. The dominant analytic framework in (Western) medical ethics is the Four Principles approach, developed in the 1970 s by the American philosophers Beauchamp and Childress, and popularized in Europe by Gillon. ${ }^{18,19}$ This method requires the moral agent to consider four principles when trying to resolve an ethical problem. These are, in no particular order:

- Respect for autonomy (i.e. respecting people's ability to make choices for themselves);

- Beneficence (i.e. providing net benefit);

- Non-maleficence (i.e. not causing net harm); and

- Justice (i.e. acting fairly).

Although the framework is maligned by some philosophers (in truth, all such frameworks are criticized by some philosophers), students can be taught how to use the four principles to identify and analyse ethical issues and can achieve various levels of proficiency in their application of the method. ${ }^{20,21}$

Aside from formal classroom teaching, students can learn to act ethically through positive role models. Alice Hamilton, a pioneering female doctor who took graduate courses at Johns Hopkins during the Osler era, noted how his students and assistants imitated his walk, gestures and expressions. No doubt they imitated his behaviour too. ${ }^{22}$ There is indeed a considerable and growing research base suggesting that medical students and junior doctors look for humanistic qualities - such as respect for patients and their families, compassion, honesty and integrity - in their positive role models, and that role models have an important function in the moral and professional development of medical trainees. ${ }^{23-26}$

\section{FAR MORE THAN ALL BOOKS ...}

During a recent anaesthesia conference, I effortlessly intubated a patient with a difficult airway. More accurately, I intubated a mannequin's head using a high-tech laryngoscope. I have little doubt that the experience would be rather different in a real-world situation. Similarly, learning about medical ethics in a lecture hall cannot be compared with learning the subject in the wards. The potentially dry discussions on informed consent or futility suddenly take on meaning when transposed to the hospital setting.

In the fifth section of Lewis Carroll's poem The Hunting of the Snark, the Beaver and the Butcher, hitherto great enemies, become inseparable friends. ${ }^{27}$ The Butcher explains to his new friend all he knows about the jubjub, a type of ferocious bird: 
'While the Beaver confessed, with affectionate looks More eloquent even than tears

It had learned in ten minutes far more than all books

Would have taught it in seventy years'

Like the Beaver, the medical student will doubtless learn more in one hospital-based ethics session than several weeks' worth of lectures in the classroom. In the ward, ethical issues are embedded in clinical reality. Rather than merely studying medical ethics, the student comes closer to 'doing' medical ethics, to applying ethical concepts and principles to real-life cases, real-life people. More obviously relevant to clinical practice, the subject becomes more memorable. A recent study on the role of professionalism and ethics training supports the view that clinically-oriented learning approaches, such as role modelling, clinical rounds, and interactions with patients, are more effective than formal didactic approaches, such as lectures. ${ }^{28}$

This Oslerian vision will require the support of senior physicians, not least to encourage members of their team to discuss common ethical issues with the students on their firm and maybe to attend some brief ethics training themselves. Medical ethicists will also need to get involved by contributing to the training and perhaps taking part in ethics rounds, as some already do in North America. Although challenging, such a method is quite achievable and, if properly conducted, should go a long way to reducing the current distaste for medical ethics among pragmatically-minded medics and, more important still, improving the all-important education of the heart.

Competing interests DS is a member of the Council of the Osler Club of London.

\section{Guarantor DS.}

Contributorship DS is the sole contributor.

Acknowledgments Thanks to Ronald P Sokol, Samantha Hettige and the JRSM reviewer for their helpful comments and to members of the Osler Club of London for their feedback on the talk on which this paper is based.

\section{REFERENCES}

1 Jonsen A. Our Lords, the Sick. In: Longo L, ed. Our Lords, The Sick. Malabar, Florida: Krieger Publishing, 2004:9-16

2 Veatch R. Disrupted Dialogue. Oxford: Oxford University Press, 2005

3 Hursthouse R. On Virtue Ethics. Oxford: Oxford University Press, 1999
4 Osler W. On the educational value of the medical society. In: Aequanimitas, With Other Addresses to Medical Students, Nurses and Practitioners of Medicine. Third edition. New York: McGraw-Hill Book Company, 1906:329-534

5 Osler W. Teaching and thinking. In: Aequanimitas, With Other Addresses to Medical Students, Nurses and Practitioners of Medicine. New York: McGraw-Hill Book Company, 1906:117-29

6 Osler W. Address to the students of the Albany Medical College. Albany Medical Annals 1899;20:307-9

7 Brody B. The Healer's Power. London: Yale University Press, 1992

8 Halpern J. From Detached Concern to Empathy: Humanizing Medical Practice. London: Oxford University Press, 2001

9 Osler W. The Evolution of Modern Medicine. New Haven: Yale University Press, 1923

10 Osler W. The fixed period. In: Aequanimitas, With Other Addresses to Medical Students, Nurses and Practitioners of Medicine. New York: McGraw-Hill Book Company, 1906:349-71

11 Bernard J. C'est de L'homme Qui S'agit. Paris: Editions Odile Jacob, 1988

12 Siegler M. A legacy of Osler. Teaching clinical ethics at the bedside. JAMA 1978;239:951-6

13 Wagner J. Teaching ethics on the wards. SGIM Forum 1996;19:4-8

14 Feudtner C, Christakis D, Christakis N. Do clinical clerks suffer ethical erosion? Students' perceptions of their ethical environment and personal development. Acad Med 1994;69:670-9

15 Mattick K, Bligh J. Teaching and assessing medical ethics: where are we now? J Med Ethics 2006;32:181-5

16 Doyal L, Gillon R. Medical ethics and law as a core subject in medical education. BMJ 1998;316:1623-4

17 Sokol D, Bergson G. Medical Ethics and Law: Surviving on the Wards and Passing Exams. London: Trauma Publishing, 2005

18 Beauchamp T, Childress J. Principles of Biomedical Ethics. Fifth edition Oxford: Oxford University Press, 2001

19 Gillon R. Philosophical Medical Ethics. Chichester: John Wiley and Sons, 1986

20 Harris J. In praise of unprincipled ethics. J Med Ethics 2003;29:303-6

21 Cowley C. The dangers of medical ethics. J Med Ethics 2005;31:739-42

22 Bliss M. William Osler; A Life in Medicine. New York: Oxford University Press, 1999

23 Paice E, Heard S, Moss F. How important are role models in making good doctors? BMJ 2002;325:707-10

24 Elzubeir M, Rizk D. Identifying characteristics that students, interns and residents look for in their role models. Med Educat 2001;35:272-7

25 Azer $\mathrm{S}$. The qualities of a good teacher: how can they be acquired and sustained? J R Soc Med 2005;98:67-9

26 Yazigi A, Nasr M, Sleilaty G, Nemr E. Clinical teachers as role models: perceptions of interns and residents in a Lebanese medical school. Med Educat 2006;40:654-61

27 Carroll L. The Hunting of the Snark: An Agony in Eight Fits: Penguin Classics, 1998

28 Roberts L, Hammond K, Geppert C, Warner T. The positive role of professionalism and ethics training in medical education: a comparison of medical student and resident perspectives. Acad Psych 2004;28: $170-82$ 